methohexitone the peak level in cord blood was maintained for up to seven minutes. In the present study the considerable difference between the two groups of infants strongly suggests a greater residual barbiturate effect in the high-dose group. The results also show that within the currently acceptable clinical usage of methohexitone the dose used to induce anaesthesia for caesarean section may be a significant factor in the aetiology of some cases of neonatal depression.

It would seem rational to relate the induction dose of methohexitone to the physical status of the mother, and the maternal weight before delivery is the most readily accessible measurement. We recommend that the dose of methohexitone used to induce anaesthesia for caesarean section should be of the order of $1 \mathrm{mg} / \mathrm{kg}$.

We thank all members of the departments of anaesthetics, obstetrics, and child health at Hammersmith Hospital who co-operated in this study, Miss Aviva Petrie of the department of statistics at the Post- graduate Medical School for statistical advice, and Miss Karen Gorman for secretarial help.

\section{References}

Coleman, A. J. (1967). Lancet, 1, 813.

Crawford, J. S. (1962). British fournal of Anaesthesia, 34, 417.

Crawford, J. S., Burton, M., and Davies, P. (1972). British fournal of Anaesthesia, 44, 477.

Dundee, J. W. and Moore, J. (1961). Anaesthesia, 16, 194

Dundee, J. W., Riding, J. E., Barron, D. W., and Nicholl, R. M. (1961) British fournal of Anaesthesia, 33, 296.

Lee, P. F. S. (1965). Acta Obstetrica et Gynecology Scandinavica, 44, 458. Marshall, J. R. (1964). Obstetrics and Gynecology, 23, 589.

McKechnie, F. B., and Converse, J. G. (1955). American fournal of Obstetrics and Gynecology, 70, 639.

Moir, D. D. (1970). British fournal of Anaesthesia, 42, 136

Price, H. L. (1960). Anaesthesiology, 21, 40

Rorke, M. J., Davey, D. A., and DuToit, H. J. (1968). Anaesthesia, 23, 585

Scott, D. B., Lees, M. M., Davie, I. T., Slawson, K. B., and Kerr, M. G. (1969). British fournal of Anaesthesia, 41, 489.

Sliom, C. M., Frankel, L., and Holbrook, R. A. (1962). British fournal of Anaesthesia 34, 316.

Sunshine, I., Whitwam, J. G., Fike, W. W., Finkle, B., and Le Beau, J. (1966). British fournal of Anaesthesia, 38, 23.

Whitwam, J. G. (1972). In Das Ultrakurznarkoticum Methohexital, ed. Charlotte Lehmann, p. 2. Berlin, Springer-Verlag.

Wilson, J., and Turner, D. J. (1969). British Medical fournal, 1, 280.

\title{
Fenoprofen in Treatment of Osteoarthrosis of Hip and Knee
}

\author{
J. A. WOJTULEWSKI, F. DUDLEY HART, E. C. HUSKISSON
}

British Medical fournal, 1974, 2, 475-476

\section{Summary}

Two studies on 41 patients with osteoarthrosis of the hip or knee have shown fenoprofen-a compound with analgesic and anti-inflammatory properties-to be an effective addition to the drug treatment of these conditions. It was found to be superior to paracetamol but no statistically significant difference was shown in a comparison with phenylbutazone.

\section{Introduction}

Fenoprofen (DL-2-(3-phenoxyphenyl)propionic acid) has demonstrable analgesic, anti-inflammatory, and antipyretic properties in animals (Nickander et al., 1971). Recently it has been shown to be effective and well tolerated in patients with rheumatoid arthritis (Fries and Britton, 1973; Huskisson et al., 1974). We have assessed its value in osteoarthrosis of the hip and knee.

\section{Study 1}

A total of 24 patients with osteoarthrosis of the hip or knees were admitted to a double-blind crossover study of single doses of fenoprofen $600 \mathrm{mg}$, paracetamol $990 \mathrm{mg}$, and placebo. Treatments were given in pairs, each patient comparing every possible pair. A patient might therefore receive fenoprofen on day 1 of the study, paracetamol on day 2 , fenoprofen on day 4 , placebo on day 5 , paracetamol on day 7, and placebo on day 8 . On the third and sixth days no trial analgesics were given. The com-

\section{Westminster Hospital, London SW1P 2AP}

J. A. WOJTULEWSKI, M.B., M.R.C.P., Senior Research Registrar

F. DUDLEY HART, M.D., F.R.C.P., Consultant Physician

St. Bartholomew's Hospital, London EC1A 7BE

E. C. HUSKISSON, M.B., M.R.C.P., Senior Registrar pounds were supplied in pink or white capsules so that each of a pair of treatments appeared to be different; one patient might compare pink fenoprofen with white placebo, while another compared white fenoprofen with pink placebo. The order of administration was randomized in a latin square design balanced for order and colour of the capsules. No other medication was allowed for six hours after administration of the test analgesics.

The analgesics were taken at about the same time each day when pain was either severe or moderately severe. After taking the capsules the patients were asked to record pain relief hourly for six hours using a simple scale consisting of no pain relief and slight, moderate, and complete pain relief. After each pair of treatments preference was recorded.

The results are shown in the chart.

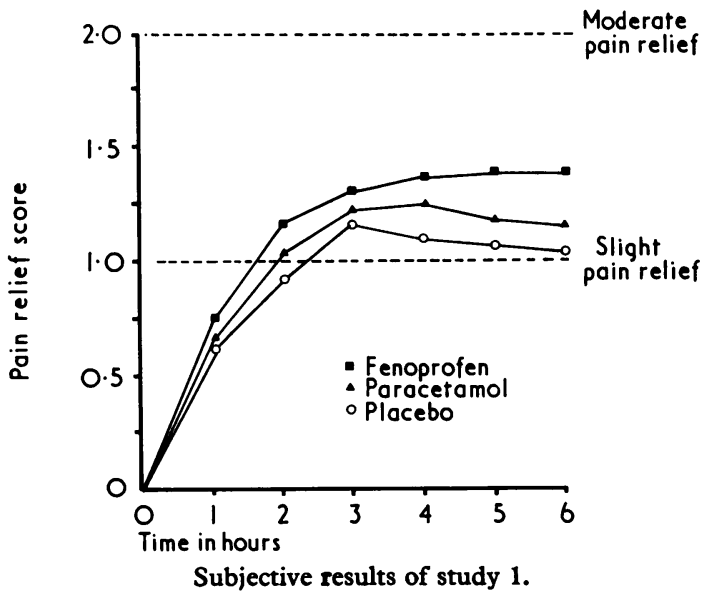

Study 2

Fenoprofen $2 \mathrm{~g}$ daily was compared with phenylbutazone $300 \mathrm{mg}$ daily on a double-blind crossover basis, each drug being given for 14 days, with an intercalated double-blind crossover 
study of Distalgesic (dextropropoxyphene hydzochloride and paracetamol) eight tablets daily and paracetamol $4 \mathrm{~g}$ daily, each being given for seven days. The treatment programme was as follows: week 1, paracetamol or distalgesic tablets; weeks 2 and 3 , fenoprofen or phenylbutazone capsules; week 4, distalgesic or paracetamol tablets; and weeks 5 and 6, phenylbutazone or fenoprofen capsules.

Out of 18 patients who entered the trial 17 completed it satisfactorily; one was withdrawn for domestic reasons. Twelve of the patients were women and five were men and their mean age was 58.8 years.

All the patients had established osteoarthrosis of one or both hips with pain of at least one month's duration, the character and severity of which were subject to only little variation. Patients with a history of peptic ulceration or of allergy or intolerance to analgesic/anti-inflammatory drugs were excluded.

Patients were seen on the last day of each period of study and their appointments were made for the same time in the morning on each of their five visits. The results of the following were recorded: (1) patients' assessment of pain severity at the time of each examination (visual analogue scale $0-20$ ); (2) patients' assessment of the overall pain severity during each period of treatment (visual analogue scale $0-20$ ); (3) quality of sleep during each treatment period (visual analogue scale 0-20); (4) intermalleolar distance (cm); (5) walking time, $15 \mathrm{~m}$ (sec.); (6) patient's opinion of the trial drug at the end of each period of study - excellent, good, fair, poor, useless; and (7) patients' drug of preference at the end of the trial. In addition the patients were asked to state which of the two one-week periods of therapy they preferred and also to give their order of preference for all four periods of treatment.

All side effects were noted and laboratory studies consisting of urine analysis, full blood count (including platelets), haemoglobin estimation, and transaminase and alkaline phosphatase estimations were performed before admission to the trial and at the end of each of the two-week periods of treatment.

When the two one-week periods of therapy were compared there was a slight preference for Distalgesic but the results were not statistically significant. When the order of preference for all

TABLE I-Study 2. Subjective and Objective Assessments in 17 Patients with Osteoarthrosis of Hip at End of Each Treatment Period. Results are expressed as Means \pm S.E.

\begin{tabular}{|c|c|c|c|}
\hline & Fenoprofen & Phenylbutazone & $\mathbf{P}$ \\
\hline 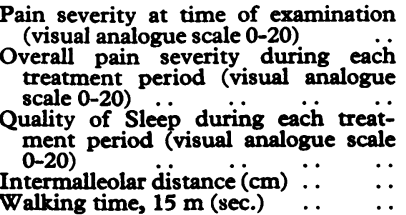 & $\begin{array}{l}10 \pm 1 \\
12 \pm 1 \\
12 \pm 1 \\
57 \cdot 2 \pm 3 \cdot 0 \\
20 \cdot 8 \pm 2 \cdot 8\end{array}$ & $\begin{array}{c}8 \pm 1 \\
13 \pm 1 \\
14 \pm 2 \\
55 \cdot 2 \pm 2 \cdot 2 \\
21 \cdot 1 \pm 3 \cdot 0\end{array}$ & $\begin{array}{l}\text { N.S. } \\
\text { N.S. } \\
\text { N.S. } \\
\text { N.S. } \\
\text { N.S. }\end{array}$ \\
\hline
\end{tabular}

four treatment periods was considered significant preference was shown for the fenoprofen or phenylbutazone periods as opposed to the Distalgesic or paracetamol periods.

The results are summarized in tables I to III.

TABLE II-Study 2. Drug Preference of 17 Patients with Osteoarthrosis of Hip

\begin{tabular}{|c|c|c|c|c|}
\hline & $\begin{array}{c}\text { No. in } \\
\text { Favour of } \\
\text { Fenoprofen }\end{array}$ & $\begin{array}{c}\text { No. in } \\
\text { Favour of } \\
\text { Phenylbutazone }\end{array}$ & $\begin{array}{l}\text { No. noting } \\
\text { No } \\
\text { Difference }\end{array}$ & $\mathbf{P}$ \\
\hline 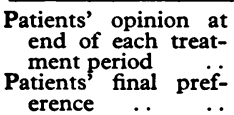 & $\begin{array}{l}6 \\
6\end{array}$ & $\begin{array}{r}8 \\
10\end{array}$ & $\begin{array}{l}3 \\
1\end{array}$ & $\begin{array}{l}\text { N.S. } \\
\text { N.S. }\end{array}$ \\
\hline
\end{tabular}

TABLE III-Study 2. Side Effects noted by 17 Patients during Treatment

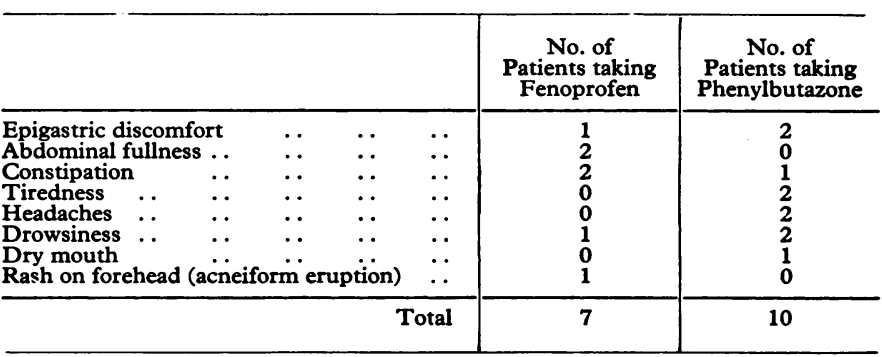

\section{Discussion}

The single-dose study shows that in terms of pain relief in osteoarthrosis fenoprofen is superior to paracetamol, which is in turn superior to placebo.

In the second study no significant difference was found between fenoprofen $2 \mathrm{~g}$ daily and phenylbutazone $300 \mathrm{mg}$ daily, though the results were marginally in favour of phenylbutazone. There was a similarly marginal preference for Distalgesic over paracetamol but a significant subjective preference for the fenoprofen and phenylbutazone periods as opposed to the two weeks with the other drugs.

Side effects were minor and presented no problems and laboratory tests showed nothing abnormal.

Fenoprofen should prove a useful addition to the drug treatment of oestoarthrosis.

\section{References}

Fries, J. F., and Britton, M. C. (1973). Arthritis and Rheumatism, 16, 629. Huskisson, E. C., et al. (1974). British Medical fournal, 1, 176.

Nickander, R. C., Kraay, R. J., and Marshall, W. S. (1971). Federation Proceedings, 30, 563. 